\title{
The tradeoff and synergy between ecosystem services in the Grain-for-Green areas in Northern Shaanxi, China
}

\author{
Xiaoqing Jia ${ }^{\mathrm{a}}$, Bojie $\mathrm{Fu}^{\mathrm{a}, *}$, Xiaoming Feng ${ }^{\mathrm{a}}$, Guohua Hou ${ }^{\mathrm{c}}, \mathrm{Yu} \mathrm{Liu}^{\mathrm{b}}$, Xiaofeng Wang ${ }^{\mathrm{a}}$ \\ a State Key Laboratory of Urban and Regional Ecology, Research Center for Eco-Environmental Sciences, Chinese Academy of Sciences, Beijing 100085, China \\ ${ }^{\mathrm{b}}$ State Key Laboratory of Ecosystem Network Observation and Modeling, Institute of Geographic Sciences and Natural Resource Research, Chinese Academy \\ of Sciences, Beijing 100101, China \\ ${ }^{\mathrm{c}}$ Tianjin University of Commerce, Tianjin 300134, China
}

\section{A R T I C L E I N F O}

\section{Article history:}

Received 22 May 2013

Received in revised form 12 February 2014

Accepted 26 February 2014

\section{Keywords:}

Ecosystem service

Tradeoff

Synergie

The Grain-for-Green project

Loess Plateau

\begin{abstract}
A B S T R A C T
As an important part of the strategy of Western development, the Grain-for-Green Program (GFGP) was initiated to protect the environment and mitigate disasters. Ecosystem services and their dynamics are considered emerging features of ecological quality and the change in direction by many scholars and practitioners. Extending from ecosystem services (ESs) modeling, we propose a simple and feasible framework for quantitatively assessing the benefits and equilibrium of the consequences of the GFGP. Our starting evaluation shows that ESs has changed dramatically in the GFGP area. By fitting pair-wise ESs' spatial concordances at the grid-cell level, we have revealed the tradeoffs between provisioning and regulating services and the synergies between the regulating services. The analysis of the variability of the relationship between ESs on different land cover types clearly identifies the vegetation that has produced exceptionally strong ESs. Our findings suggest that quantifying the interactions between ESs may improve the ecosystem-based management practices and support policy-making to address the challenges of the sustainable use of natural resources. The framework designed for regional-scale analysis can help in clearly understanding the interrelations of ESs and make natural resources related decisions more effective and efficient, although this framework still needs to move beyond these fundamental and illustrative analyses to more fully explain the synergies and tradeoffs.
\end{abstract}

(c) 2014 Elsevier Ltd. All rights reserved.

\section{Introduction}

Human activities are now widely accepted as the main driver of the Earth's surface transformation (Vitousek, 1997; Foley et al., 2005). One of the world's most ambitious ecosystem conservation set-aside programs is the Grain for Green Program launched in China in 1999 (Uchida et al., 2005; Chen et al., 2009). Studies have shown that the cumulative contributions of GFGP to the ecosystems in China and the world are tremendous (Liu and Diamond, 2005; Liu et al., 2008). Specifically, GFGP has fundamentally improved ecosystem services by increasing vegetation cover, decreasing water surface runoff and soil erosion, and reducing river sediments and nutrient loss to maintain soil fertility (Liu et al., 2002; Ma and Fan, 2005; Li et al., 2006; Long et al., 2006;

\footnotetext{
* Corresponding author at: State Key Laboratory of Urban and Regional Ecology, Research Center for Eco-Environmental Sciences, Chinese Academy of Sciences, P. O. Box 2871, Beijing 100085, China. Tel.: +86 10 62923557; fax: +86 1062923557. E-mail address: bfu@rcees.ac.cn (B. Fu).
}

Xu et al., 2006). The enhancement of the supply of ecosystem services (ESs) has led to declines in many other ESs (Rodríguez et al., 2006; Bennett and Balvanera, 2007), as evidences have emerged that intentional management options that are beneficial for one service may cause a cross-balance that reduce the benefits for other services (D'Amato et al., 2011; Dickie et al., 2011). For example, the purposeful removal of vegetation for cultivation increases soil erosion and overgrazing by animal husbandry causes land cover and soil degradation. Finding out how ESs interactions change as land use and management changes may help avoid unnecessary losses by focusing on finding the most efficient solutions to mitigate the tradeoffs or to enhance synergism and maximize the desirable values (White et al., 2012). Identifying the tradeoffs and synergies among ESS is likely to improve ecosystem-based management practices and strengthen the decision-making processes to achieve specific objectives (Carreno et al., 2012).

To better understand and take advantage of the relationship between ESs, much work has been done to examine how multiple ESs correlate with each other theoretically, from which humans can benefit. Studies have showed that biodiversity conservation 


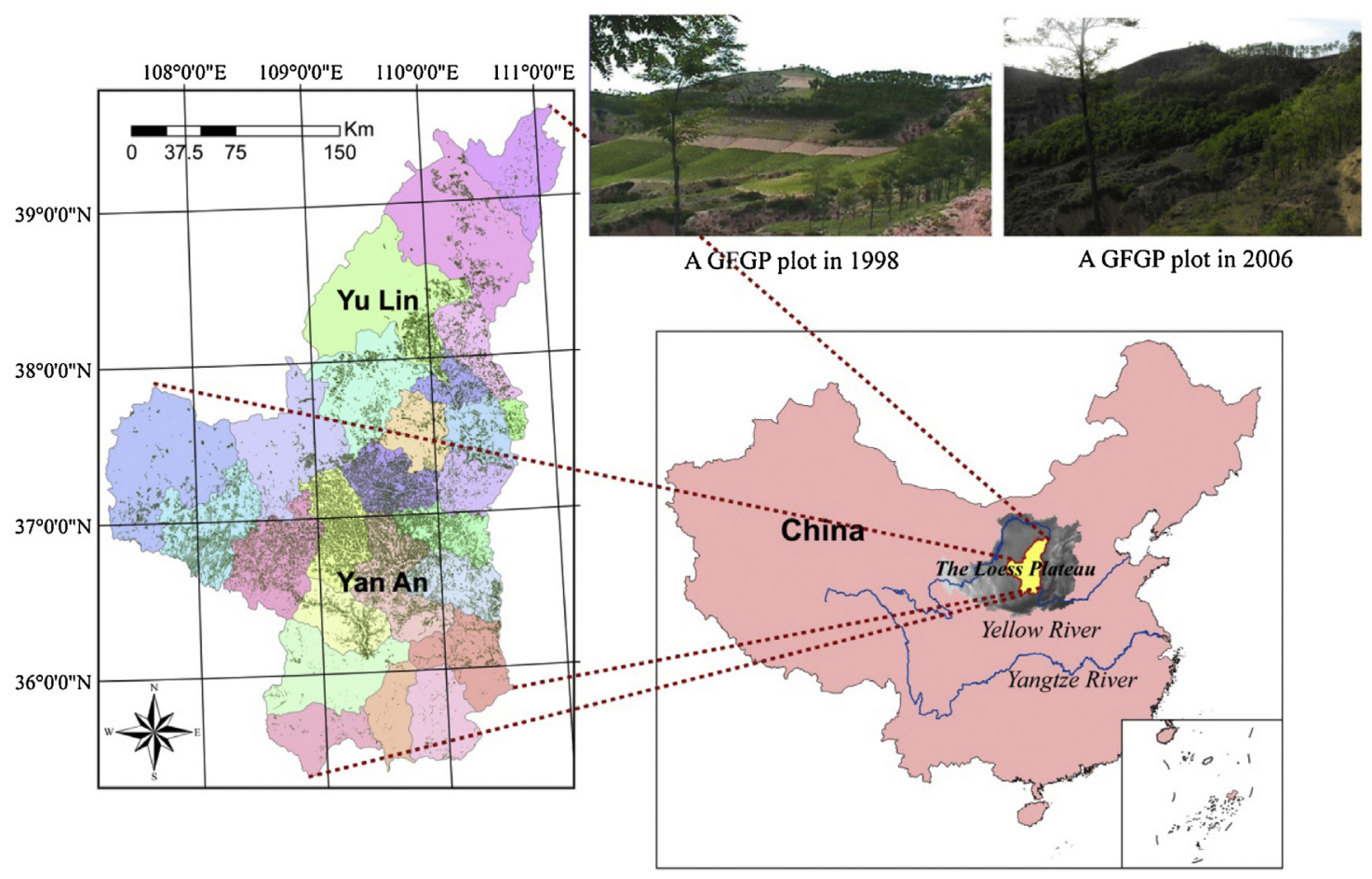

Fig. 1. Location and appearance of the Grain for Green plots in Northern Shaanxi.

protects the substantial collateral flows of services like carbon sequestration, water provision, and grassland production (Chan et al., 2006). Likewise, a spatially explicit examination of the performance of biodiversity conservation and ESs showed only a small tradeoff among ESs during their development (Nelson et al., 2009). The preservation of ecosystems services has proven to have positive effects on habitats and species conservation status on a European scale with statistical models playing an important role in Maes et al.'s (2012) study. By extending spatially explicit tradeoff analyses from economic value based on marine spatial planning, White et al. (2012) developed a policy window method to indicate sector value flows and prevalent spatial conflicts over marine ESs. For quantitatively accessing the consequences of different forest management options in terms of benefits and tradeoffs among multiple objectives, an ecosystem functional framework is now available (Bradford and D'Amato, 2012).

As quantification and evaluation were conducted intensively and thoroughly for specific cases and experimental analysis, other important factors, including the temporal and spatial scales, the data availability, and the applicable models should be taken into account in the assessment of ESs interactions. Identifying tradeoffs and synergies at one point in time and space would bring incorrect assumptions about the mechanisms behind these relationships and hence managing them would likely be ineffective (Bennett et al., 2009). Human management of ecosystems may cause a mutual conversion between tradeoffs and synergies that arise as the spatial scales move up, bringing about desirable or undesirable outcomes (Heal, 2000; Balvanera et al., 2001). Addressing these challenges requires accounting for mainstream ESs spatio-temporally at different scales during LULC changes (McNally et al., 2011; Dymond et al., 2012). Along with the growing recognition of integrating ESs into ecosystem-based management decisions, spatial patterns of ESs across landscapes should be more broadly explored (Egoh et al., 2008; Tallis et al., 2009). However, policy makers are still limited in implementing practical measures for managing ESs (Dickie et al., 2011) lacking straightforward, user-friendly approaches for characterizing the individual and combined synergies and tradeoffs of multiple objectives explicitly or transparently (Bradford and D'Amato, 2012).

Considering the limitations of the current studies on ESs interactions, we propose a framework to provide a relatively simple and transparent method for creating spatially-explicit simulations of ESs relations under LULC conversion scenarios. Ecological benefits and ecosystem services have been improved after years of efforts by converting sloping croplands to forests or grasslands, putting the scientific grounds for studying ESs interactions on a large-scale. Our overall goal is to identify tradeoffs and synergies between ESs and examine how they are balanced with land cover changes. We quantified carbon sequestration, surface runoff, evapo-transpiration, soil conservation, and their interactions for GFGP area in Northern Shaanxi, to create relatively quick projections of numerous categorical data for distribution. Spatial concordances between multiple ESs were then evaluated by aligning geographic and statistic methods to reveal the balancing mechanism of ESs interactions. The work's specific objectives include (i) quantifying the ESs applied to regionally validate the models, (ii) identifying land cover transition areas from 2000 to 2008 (Loring et al., 2008) to provide an spatially explicit statistical basis for elucidating synergies and tradeoffs between ESs at the grid cell-level, and (iii) illustrating ESs variations in the processes of improving the eco-environment. We conclude by discussing the implications for management and decision-making.

\section{Materials and methods}

\subsection{Study area}

Located in the northern part of Shaanxi Province, China $\left(35^{\circ} 21^{\prime}\right.$ $\mathrm{N}-39^{\circ} 34^{\prime} \mathrm{N}, 107^{\circ} 28^{\prime} \mathrm{E}-111^{\circ} 15^{\prime} \mathrm{E}$ ), the core GFGP area (Fig. 1 ) covers an area of $7923 \mathrm{~km}^{2}$ with an elevation ranging from 411 to $1911 \mathrm{~m}$. The region is in the middle of the Loess Plateau which is characterized by typical Loess hills and gullies and dominated by a semi-arid continental monsoon climate. Annual average temperature varies from about $6.5^{\circ} \mathrm{C}$ in the north to $12.5^{\circ} \mathrm{C}$ in the south, and annual 
average precipitation is approximately $450 \mathrm{~mm}$ in the south and gradually decreases to $250 \mathrm{~mm}$ in northwestern direction, with $60-70 \%$ of the rainfall occurring in the rainy season from July to September (Fu et al., 1999). The soil is mainly derived from loess with fine silt to silt in texture and is vulnerable to erosion. Land-use types in this area are primarily slope farmland, terrace farmlands, grasslands, shrubs, sparse forestlands, and forestlands. Before the GFGP was launched, the hilly topography, concentrated precipitation, and improper anthropogenic land-use activities were the main causes of water loss and soil erosion in the area. After years of efforts being made to convert croplands to forests, shrubs or grasslands, the regional ecosystem services changed dramatically.

\subsection{Land use/land cover change}

We classified LANDSAT TM/ETM images with $30 \mathrm{~m}$ resolution and all of the six spectral bands were used to generate the baseline land use/land cover map (LULCM) in 2000 for the GFGP area. For the LULCM in 2008, we applied the images from the China-Brazil Earth Resources Satellite (CBERS-2b) with a resolution of $19.5 \mathrm{~m}$. A series of $1: 100,000$ relief maps were used to rectify the images and 30 evenly distributed sites were selected as Ground Control Points for each scene before the mosaic and the interpretation of LANDSAT TM/ETM images. The Root Mean Squared Error of geometric correction was less than one pixel. An accuracy assessment for the classification in 2008 was conducted to support the validation of LULCM. Based on ground referencing data collected during field visits in 2008, the classification accuracy reached 95\%. A total of eight classes of land covers were defined for the GFGP area. The transition area was further grouped into three aggregated types: croplands to forestlands, croplands to shrubs and croplands to grasslands.

\subsection{Quantification of ecosystem services}

Land-use and land-management decisions have major impacts on ecosystems and the goods and services they provide to people (Daily, 1997). Following the LULC classification, we modeled ecosystem services for the GFGP area to better understand how the interactions between ESs are affected by changes of LULC. The ESs is quantified in terms of soil conservation, surface runoff, evapotranspiration, and net primary productivity (NPP) for 2000 and 2008 by applying regional revised empirical equations.

\subsubsection{Soil conservation}

Located in the middle of the Loess Plateau, the study area has suffered terrible soil erosion in recent decades (Shi and Shao, 2000). Hence, soil conservation, a relative measurement of soil loss, is regarded as one of the significant indicators of the improvement of ESs for the area. Soil conservation was estimated for 2000 and 2008 by computing soil retention by applying the Revised Universal Soil Loss Equation (RUSLE) (Renard et al., 1997). Soil retention is calculated as soil loss supposedly ignoring vegetation cover and soil erosion control practices minus the current LULC patterns and soil erosion control practices. According to locally developed specific methods calculating factors of the USLE for the Loess Plateau (Zhang et al., 2004; Fu et al., 2005), the equation is expressed as:

$\Delta A=A_{o}-A_{v}=R \times K \times L \times S \times\left(1-C_{v} \times P_{v}\right)$,

where $\Delta A$ is the average annual soil loss $\left(\mathrm{tha}^{-1} \mathrm{y}^{-1}\right) ; A_{v}$ and $A_{o}$ are the soil loss with and without vegetation cover separately; $R$ is the rainfall-runoff erosivity (MJ mm ha ${ }^{-2} \mathrm{ha}^{-1} \mathrm{y}^{-1}$ ) based on monthly rainfall; $K$ is the soil erodibility $\left(\mathrm{t} \mathrm{ha} \mathrm{MJ}^{-1} \mathrm{~mm}^{-1}\right.$ ) derived from Soil Survey Office of Shaanxi Province; $L$ is the slope length; $S$ is the steepness calculated by ARCGIS 9.3; $C_{v}$ is the cover management practice following (Cai et al., 2000); and $P_{\nu}$ is the support practice adopting slope-based Wener's method (Lufafa et al., 2003) (both ranges between 0 and 1 ). The latter four parameters are all dimensionless.

\subsubsection{Water yield}

Characterized by scarce yet concentrated water resources, the semi-arid Loess Plateau area is controlled mostly by precipitation (PPT) and evapo-transpiration (ET) (Budyko, 1974; Potter et al., 2005). Resulting from the balancing between PPT and ET, water yield was necessarily selected as an indicator of hydrological regulation ESs. The annual water yield $Q$ is calculated as:

$Q=P P T-E T \pm \Delta S \approx P P T-E T$,

based on the assumption that the water storage change $(\Delta S)$ is negligible at regional and long time scales. The monthly ET ( $\mathrm{mm})$ can be sufficiently predicted by potential ET (PET), precipitation, and leaf area index (Sun et al., 2011a), and can be estimated by

$E T=9.78+0.0072 \times P E T \times P P T+0.051 \times P P T \times L A I$,

where PET represents potential ET ( $\mathrm{mm}$ ) and $L A I$ represents leaf area index (dimensionless). PPT was derived from 172 weather stations within and near the GFGP region (State Bureau of Meteorology, 2011, http://cdc.cma.gov.cn/home.do). PET was calculated using a simpler Hamon PET method (Hamon, 1963). LAI was acquired from simulation of the relationship between NDVI and LAI for different types of land cover (Zhang et al., 2008c) using SPOT VEGETATION NDVI. The coefficients of the function are defined through the calibration for the equation with stream data monitored by the Yellow River Conservancy Commission. Validation for the equation was conducted by statistically modeling of the relations between observed field data and estimated data.

\subsubsection{Net primary productivity}

Produced in the plant photosynthesis process to form the key components of organisms, net primary productivity (NPP) is the important driver of the terrestrial carbon cycling, balancing $\mathrm{CO}_{2}$ and $\mathrm{O}_{2}$ and regulating global temperature. The increment of NPP would enhance gas regulation and climate regulation services (Costanza et al., 1997) on the Loess Plateau sensitive to climate changes, in particular in the area where GFGP is implemented. NPP was evaluated employing the Carnegie-Ames-Stanford Approach (Potter et al., 1993; Boccalandro et al., 2012), a process-based model expressed as

$N P P=F(N D V I, S O L) \times \varepsilon^{*} \times g(T) \times h(W)$.

Reflecting different vegetation canopies, NDVI (normalized difference vegetation index) was derived from NOAA/AVHRR Land dataset. SOL $\left(\mathrm{MJ} \mathrm{m}^{-2}\right)$ represents monthly total solar radiation, obtained on the basis of Allen et al.'s (1998) method. $\varepsilon^{*}$ (dimensionless) is the maximal light utilization efficiency of the vegetation in ideal conditions. $g(T)$ includes two temperature stress coefficients described in detail by Potter et al. (1993) and $h(W)$ stands for water stress calculated using the method from Piao et al. (2001).

\subsubsection{Model evaluation}

We have validated the quantification of ESs yet uncertainty is inevitable because of the limitations of the models. RUSLE was developed based on the erosion data from field plots in the Midwest of the U.S. Therefore, simply borrowing the model with locally calculated factors may lead to deviation from the actual situation. This model has been criticized for being ineffective for estimating deposition and sediment yield under various conditions, especially in predicting gully erosion (Fu et al., 2005; Beskow et al., 2009). Overestimation may occur on slopes steeper than $30 \%$ owing to the USLE algorithms which are highly sensitive to slope gradients (Liu 
et al., 1994). Considering the limitations above, we made considerable adjustments and referred to experimental parameters for the GFGP region to determine the key factors.

The seasonal and inter-annual variability of precipitation is the main cause of the gap between the water yield modeling results and the MODIS data product. Uncertainty also exists in the estimation of ET for two reasons: (1) change in water storage may not have been negligible for certain wet years and (2) water resource use by communities and the impacts of soil conservation structures (e.g., check dams) were not involved. Overall, the method we adopted may introduce systematic errors at a level of approximately $15 \%$ (Sun et al., 2011b).

The CASA model at the stand level has been developed in great detail, nevertheless, the difference in mechanisms between the model system and ecological processes may cause problems on a large scale. The NPP modeling results is largely depending on the accuracy of input data. LANDSAT and CBERS-2b images with a resolution of $30 \mathrm{~m}$ and $19.5 \mathrm{~m}$, atmospheric corrected NDVI data and monthly meteorological data were used to reduce the uncertainties of the model.

\section{Results}

\subsection{Land use/land cover change}

A dramatic change of the LULC pattern has taken place in the administrative area where GFGP was carried out from 2000 to 2008.
Table 1

Major vegetation cover in the GFGP plots located in 25 counties in 2000 and 2008. The unit of area is $\mathrm{km}^{2}$ and $100 \%$ for change rate.

\begin{tabular}{lrrr}
\hline & Area in 2000 & Area in 2008 & Change rate (\%) \\
\hline Cropland & 28,096 & 20,314 & -27.7 \\
Arbors & 4595 & 4750 & 3.4 \\
Shrubs & 8783 & 14,342 & 63.3 \\
Grass & 31,760 & 33,881 & 6.7 \\
Construction & 71 & 117 & 6.5 \\
\hline
\end{tabular}

All of the eight classes shifted to different degrees, among which croplands were the largest transformation type. The croplands covering $28,096 \mathrm{~km}^{2}$ in 2000 decreased to $20,314 \mathrm{~km}^{2}$ in 2008 , with a reduction of approximately $27.7 \%$ (Table 1 ). On the contrary, the area of shrubs, grasslands and forests increased by $63.3 \%, 6.7 \%$, and $3.4 \%$ over the eight year period, with natural succession, species intrusion, and other unavoidable impact factors contributing to the portion of $19.1 \%$. Since croplands restored to plantations are enrolled in the total GFGP area, they are the only change types considered in the research. The conversion of land cover was discovered to occur mainly from croplands to shrubs, dominating $70 \%$ of the total transformed area. Other forms of alterations were happening in the meantime, given that $27.8 \%$ and $2.2 \%$ of the grasslands and forestlands spread separately through of the original croplands.
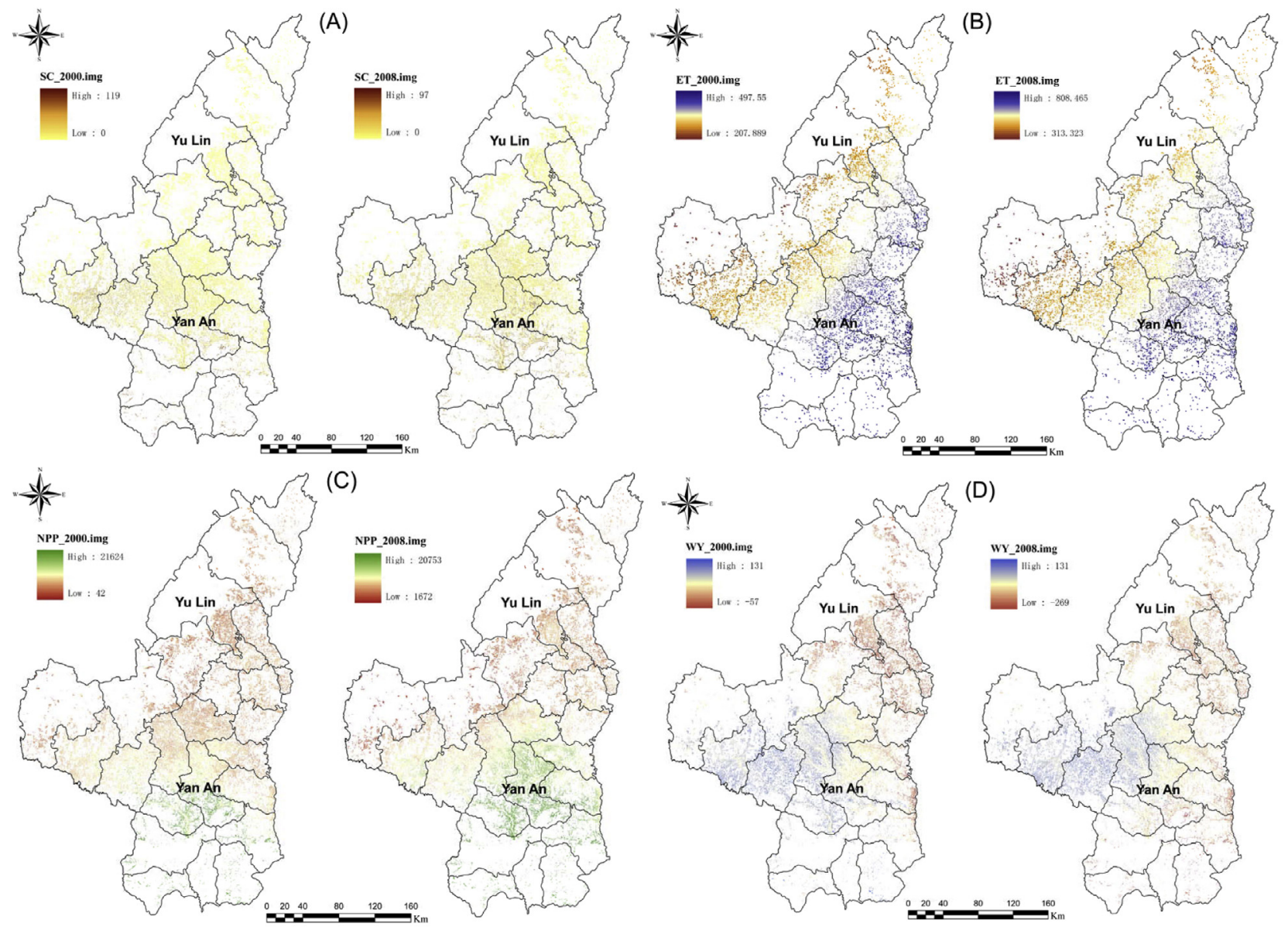

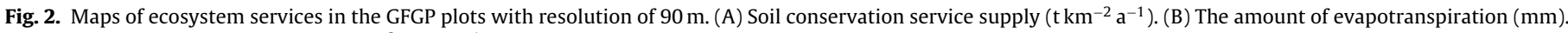
(C) Net primary productivity ( $\mathrm{g}$ carbon $\mathrm{m}^{-2} \mathrm{month}^{-1}$ ) to regulate climate and gas. (D) The volume of water yield (mm). 
Table 2

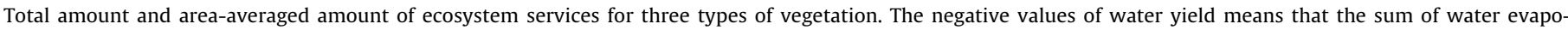
transpiration is greater than precipitation and river feedings. The unit of SC and NPP are $\mathrm{kg}$, for WY and ET are mm and for area-averaged multiplied by km ${ }^{-2}$.

\begin{tabular}{|c|c|c|c|c|c|c|c|c|}
\hline & SC_2000 & SC_2008 & $\begin{array}{l}\text { SC_2000 } \\
\text { area-averaged }\end{array}$ & $\begin{array}{l}\text { SC_2008 } \\
\text { area-averaged }\end{array}$ & NPP_2000 & NPP_2008 & $\begin{array}{l}\text { NPP_2000 } \\
\text { area-averaged }\end{array}$ & $\begin{array}{l}\text { NPP_2008 } \\
\text { area-averaged }\end{array}$ \\
\hline Arbors & $2.97 \times 10^{6}$ & $1.28 \times 10^{7}$ & $0.65 \times 10^{-3}$ & $0.26 \times 10^{-2}$ & $1.7 \times 10^{5}$ & $4 \times 10^{5}$ & 37.05 & 84.31 \\
\hline Shrubs & $2.03 \times 10^{8}$ & $6.41 \times 10^{8}$ & $0.23 \times 10^{-1}$ & $0.45 \times 10^{-1}$ & $4.3 \times 10^{5}$ & $1.41 \times 10^{6}$ & 48.97 & 98.21 \\
\hline \multirow[t]{2}{*}{ Typical grass } & $3.32 \times 10^{7}$ & $1.25 \times 10^{8}$ & $0.1 \times 10^{-2}$ & $0.37 \times 10^{-2}$ & $1.2 \times 10^{6}$ & $2.46 \times 10^{6}$ & 37.86 & 72.56 \\
\hline & WY_2000 & WY_2008 & $\begin{array}{l}\text { WY_2000 } \\
\text { area-averaged }\end{array}$ & $\begin{array}{l}\text { WY_2008 } \\
\text { area-averaged }\end{array}$ & ET_2000 & ET_2008 & $\begin{array}{l}\text { ET_2000 } \\
\text { area-averaged }\end{array}$ & $\begin{array}{l}\text { ET_2008 } \\
\text { area-averaged }\end{array}$ \\
\hline Arbors & $-2.18 \times 10^{4}$ & $-6.54 \times 10^{4}$ & -4.74 & -13.76 & $1.53 \times 10^{6}$ & $1.72 \times 10^{6}$ & 334.06 & 362.78 \\
\hline Shrubs & $5.13 \times 10^{4}$ & $-1.11 \times 10^{5}$ & 5.84 & -7.71 & $3.17 \times 10^{6}$ & $5.35 \times 10^{6}$ & 361.42 & 372.86 \\
\hline Typical grass & $-5.71 \times 10^{5}$ & $-9.37 \times 10^{5}$ & -17.97 & -27.66 & $9.86 \times 10^{6}$ & $1.08 \times 10^{7}$ & 310.95 & 318.32 \\
\hline
\end{tabular}

\subsection{Variations of ecosystem services}

In general, ecosystem services have experienced various alterations driven by the GFGP. The northern part covering up to three-fourths of the Shaanxi Province suffered from severe erosion and slightly eroded areas were mainly clustered in the south. With the implementation of GFGP, the erosion has gradually been curbed, especially in the south (Fig. 2(A)). In the areas converted to forests, the capacity of conserving soil grew to the highest, multiplied by 4.3 times and 4.16 times area-averaged in eight years. This was followed by the grasslands, for which the soil conservation ability was estimated to have increased by over $4 \times 10^{4} \mathrm{t} \mathrm{km}^{-2}$ and 2.5-fold for per kilometer in 2008. For the area changed to shrubs from croplands, the rate of soil retention trebled in total and doubled that of 2000 for per unit area (Table 2).

The varied distributions of hydrological regulation services implied a complex ecological process. Fig. 2(B) and (D) shows that the middle-southern area through which the YanHe and LuoHe rivers pass was important for evapo-transpiration (ET) and surface water yield in 2000. ET grew from southeast to northwest, while surface water yield decreased prominently in the dispersed plant community in north and south than the river shed. Covering the largest area, the water shrubs altogether retained is about 3.16 times as much as in croplands eight years later with per unit amount increased by $132 \%$. While occupying the least area among three types of plantation, surface water reduction almost trebled both in all and for per unit area when croplands were converted to forestlands. In response, increased vegetations produced corresponding evapo-transpiration to the atmosphere after the ecological rehabilitation. Shrubs' ET grew to $168 \%$ totally but only by $3 \%$ per square kilometer, whereas its amount had grown by $12 \%$ and $9 \%$ for per unit in arbores. The smallest changes ET happened in the grasslands, increasing by $10 \%$ in gross and $2 \%$ in per unit.

The carbon cycling level surrogated by net primary productivity (NPP) also experienced a notable change. Like the soil conserving and water regulating services, NPP was also greatest in the southern densely vegetated area. Along with the nonproductive planting, the aboveground carbon stores accumulated steadily from north to south, except for the northwest edge (Fig. 2(C)). It is assessed
NPP grew 2.35 times in the area where croplands were converted to forestlands and 2.28 times for per unit area, the highest in all transformation types. Shrubs have fixed roughly thrice the carbon of that in croplands and generally twice the amount on averaged cropland area after eight years. For grasslands, the amount of carbon they sequestered has been doubled in total and has risen by $92 \%$ per unit area.

\subsection{Relationships between ecosystem services}

Spatial concordance among ecosystem services on a regional scale was assessed using logistic regression models that have been verified to perform best for the study area after fitting with other classic regression models. Interactions were visualized by plotting ESs values against each other in $1 \mathrm{~km}$ grid cells based on ESs productions. ESs of soil conservation (SC), water yield (WY), and evapo-transpiration (ET) were found to have significant $(P<0.0001)$ correlations with carbon cycling service at different levels. By matching spatially distributed data at the grid-cell level, ET related best $\left(R^{2}>0.5\right)$ with NPP among all pair-wise relationships (Table 3 ). The large-scale and short-term plantation strengthened the relationship between ET and NPP biomass in 8 years, making them easier to be explained by each other. SC showed a moderate $\left(0.5>R^{2}>0.2\right)$ positive correlation with NPP on forestland and weak $\left(R^{2} \leq 0.2\right)$ (Fig. 3) correlations on the other two types of land cover. The severity of ESs interactions was distinguishable across different land covers, as forest is more efficient in promoting positive relationship between SC and NPP. ET and WY responded to NPP the strongest on grasslands compared to the other two types of land cover (Figs. 4 and 5), with their total amount in some area in the north influenced by rainfall distribution (Fig. 2(D)). Under a massive plantation project starting to change the way ESs correlated with each other, tradeoffs and synergies became apparent across time. The correlation modeling of ET and WY with NPP presented fitting curves significant with similar frontiers, implying a spatial inconsistency between ESs at the beginning of GFGP. Transpiration and photosynthesis of broadly introduced plants enhanced the regulation services that exhibited obvious positive and negative correlations after eight years of efforts.

Table 3

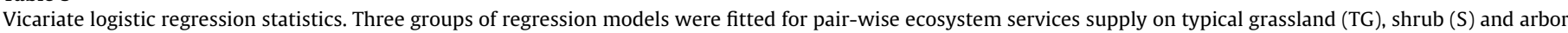

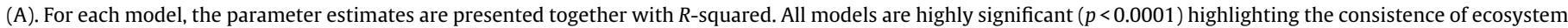
services result of ecological process model.

\begin{tabular}{|c|c|c|c|c|c|c|}
\hline & ET_NPP & $R^{2}$ & WY_NPP & $R^{2}$ & SC_NPP & $R^{2}$ \\
\hline TG_2000 & $\mathrm{ET}=565-305 /(1+(\mathrm{NPP} / 7406) \hat{2})$ & 0.73 & $\mathrm{WY}=31-347 /(1+(\mathrm{NPP} / 4099) \hat{1} 1)$ & 0.31 & $\mathrm{SC}=655-655 /(1+(\mathrm{NPP} / 149,386) \hat{3})$ & 0.19 \\
\hline TG_2008 & $\mathrm{ET}=7 \mathrm{E}-4 \times \mathrm{NPP}^{2}+10 \mathrm{E}-7 \times \mathrm{NPP}+257$ & 0.83 & $W Y=-19,512-19,576 /(1+(N P P / 108,269) \hat{3})$ & 0.53 & $\mathrm{SC}=10-9 /(1+(\mathrm{NPP} / 18,028) \hat{3})$ & 0.21 \\
\hline S_2000 & $\mathrm{ET}=507-268 /(1+(\mathrm{NPP} / 4518))$ & 0.60 & $\mathrm{WY}=37+1 /(1+(\mathrm{NPP} / 430) \hat{5})$ & -0.15 & $\mathrm{SC}=319-319 /(1+(\mathrm{NPP} / 218,066) \hat{2})$ & 0.12 \\
\hline S_2008 & $\mathrm{ET}=1102-816 /(1+(\mathrm{NPP} / 30254) \hat{2})$ & 0.73 & $W Y=-481+551 /(1+(N P P / 35,961) \hat{2})$ & 0.50 & $\mathrm{SC}=13-12 /(1+(\mathrm{NPP} / 22,956) \hat{3})$ & 0.14 \\
\hline A_2000 & $\mathrm{ET}=637-963 /(1+(\mathrm{NPP} / 579))$ & 0.50 & $W Y=22-22 /(1+(N P P / 2728) \hat{4} 83)$ & 0.20 & $\mathrm{SC}=413-413 /(1+(\mathrm{NPP} / 63,031) \hat{4})$ & 0.22 \\
\hline A_2008 & $\mathrm{ET}=114,030-113,777 /(1+(\mathrm{NPP} / 2 \mathrm{E} 6))$ & 0.71 & $W Y=-25,882+25,940 /(1+(\mathrm{NPP} / 88,224) \hat{4})$ & 0.42 & $\mathrm{SC}=493-493 /(1+(\mathrm{NPP} / 142,003) \hat{2})$ & 0.32 \\
\hline
\end{tabular}


(A)

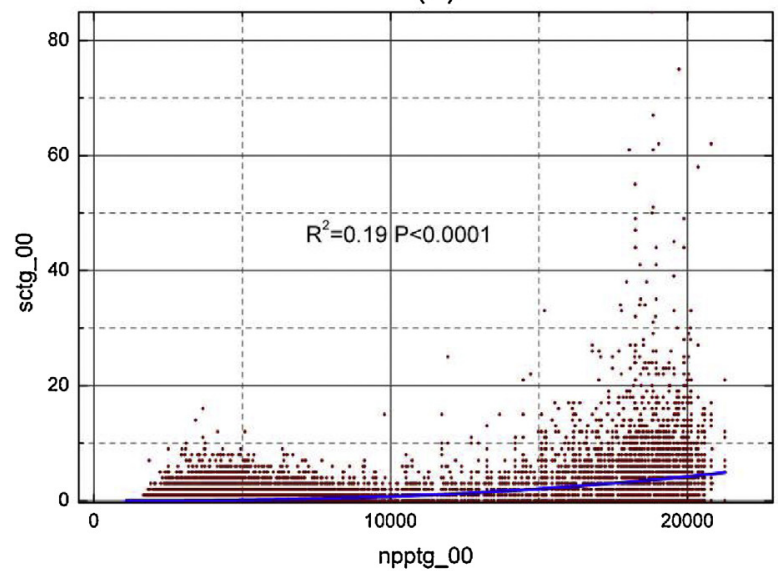

(A)

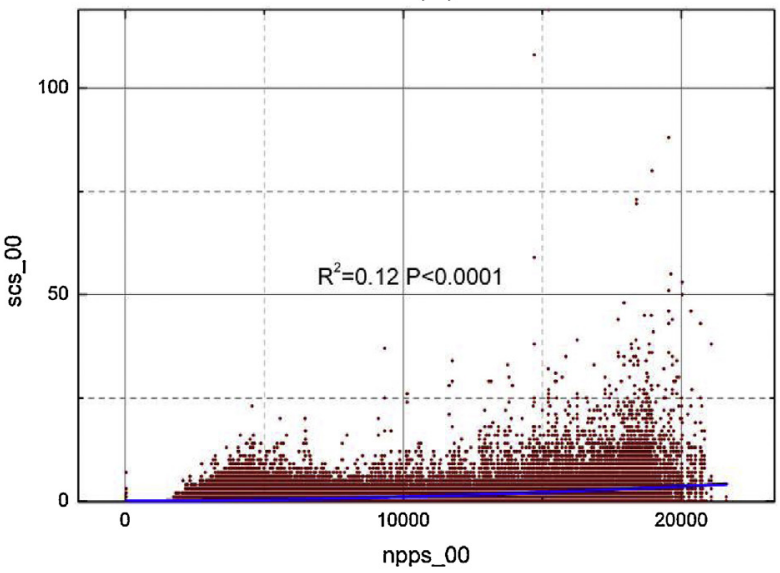

(A)

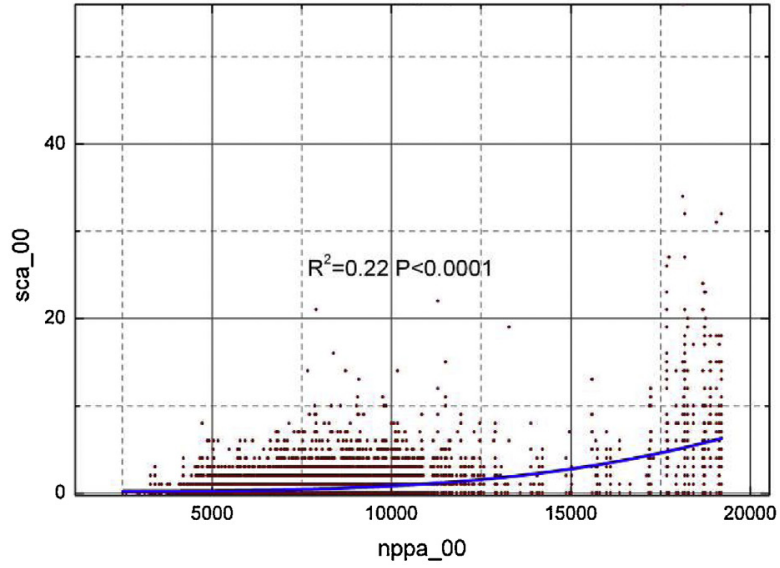

(B)

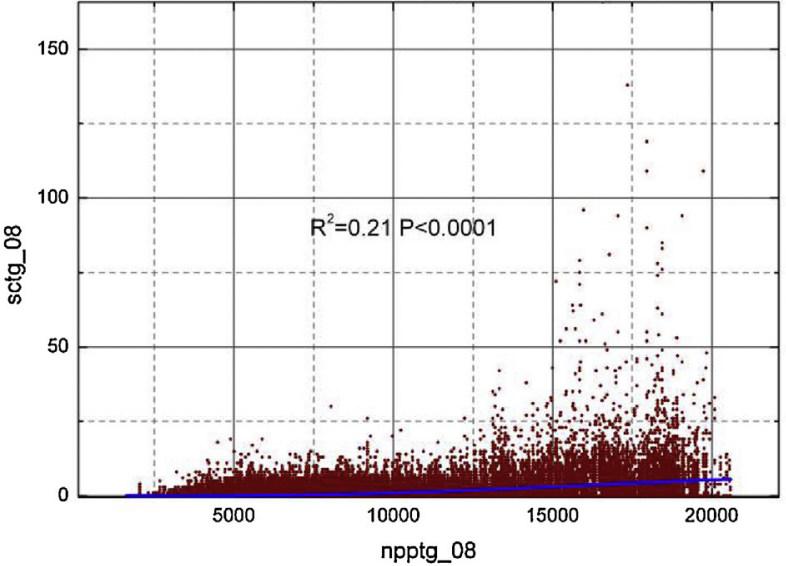

(B)

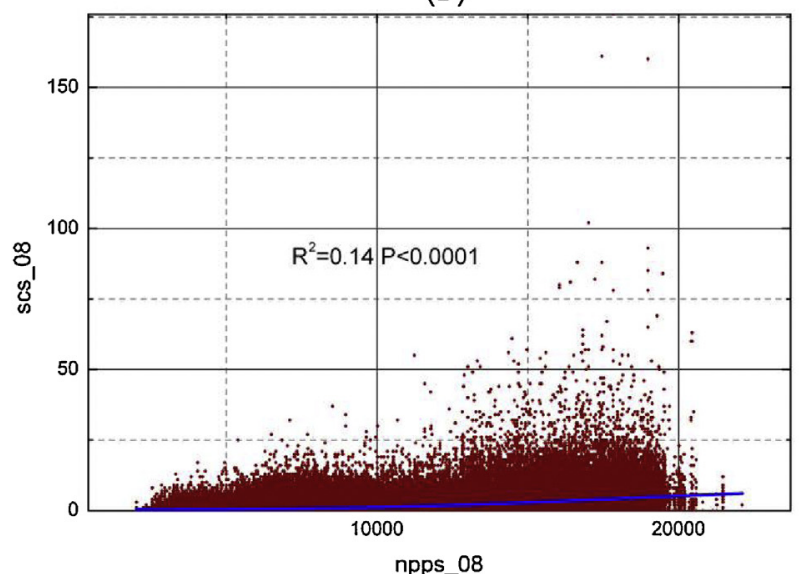

(B)

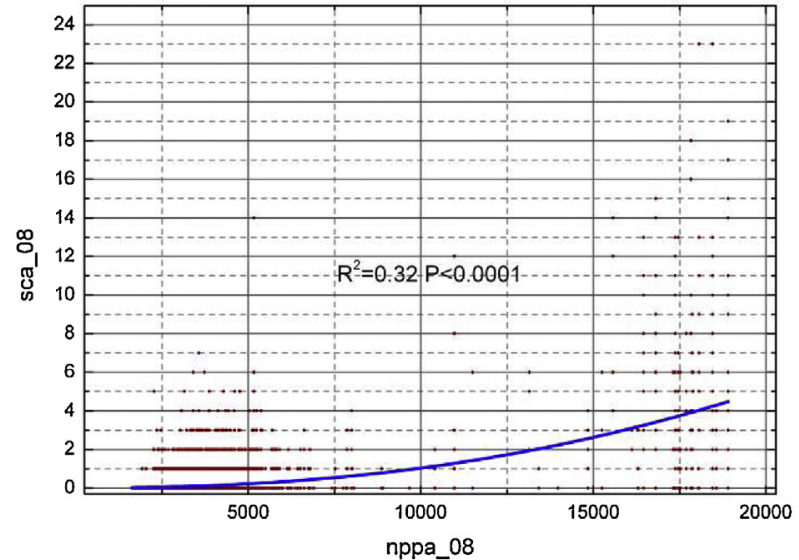

Fig. 3. Synergies between net primary production and soil conservation at grid-cell level.

\section{Discussion}

\subsection{Effects of GFGP on ecosystem services}

China is a densely populated country with less cultivated land. Under the pressure of the growing population and expanding production, hilly slope lands were largely reclaimed for cultivation to survive human beings. By the end of 2011, over 435 billion yuan (about US $\$ 70.5$ billion) had been invested in the GFGP converting 28.47 million hectares of sloping farmlands to have achieved enormous ecological effects. The regional ecological effects were found to differ among different types of plantation influenced by how many areas were converted and when they were converted. Covering converted land in 25 counties, nearly 100,000 tons of sediments were blocked from flowing into the Yellow River in 2008 compared with 2000 altogether. Ecosystem service of soil retention grew the fastest on areas planted with arbores that reinforced soil fixation by increasing soil shear strength (Anderson and Richards, 1987; Coppin and Richards, 1990; Operstein and Frydman, 2000), providing structural support, or lowering the pore water pressures in the soil (Gray and Sotir, 1996) through their root systems, thus preventing around $1.64 \%$ of the total sediment blocked. Meanwhile, the shrubs protect more than $6.4 \times 10^{5}$ tons from the natural carrying processes since most area of sloping land was converted to 
(A)

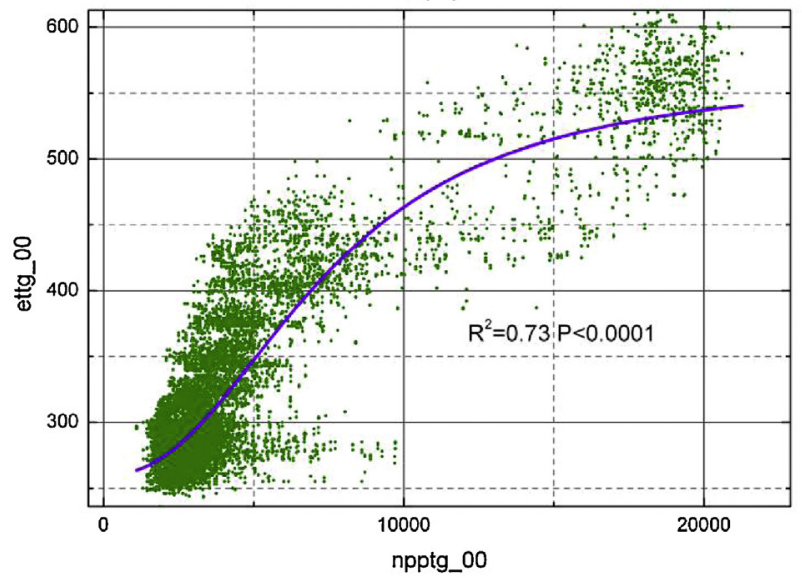

(A)

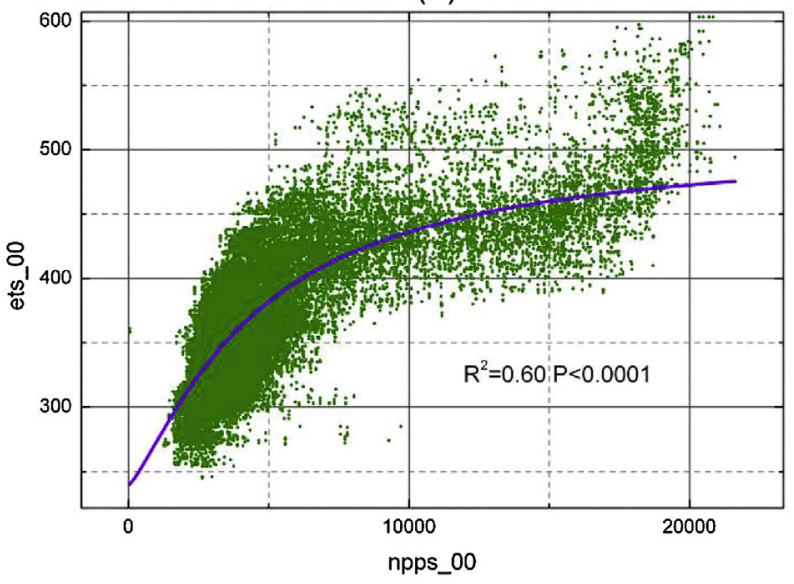

(A)

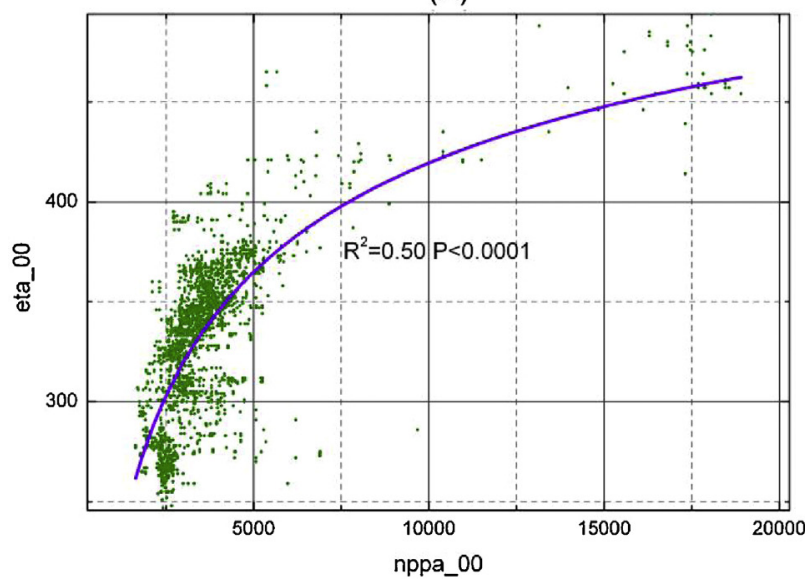

(B)

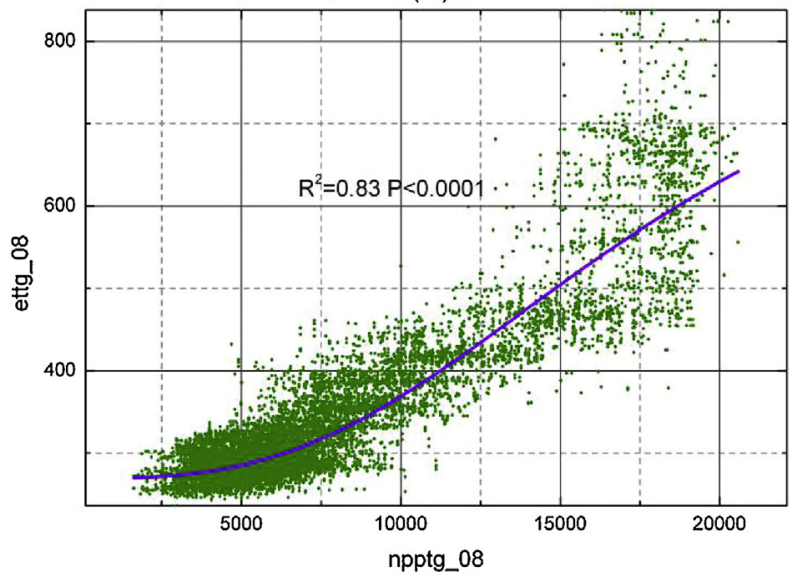

(B)

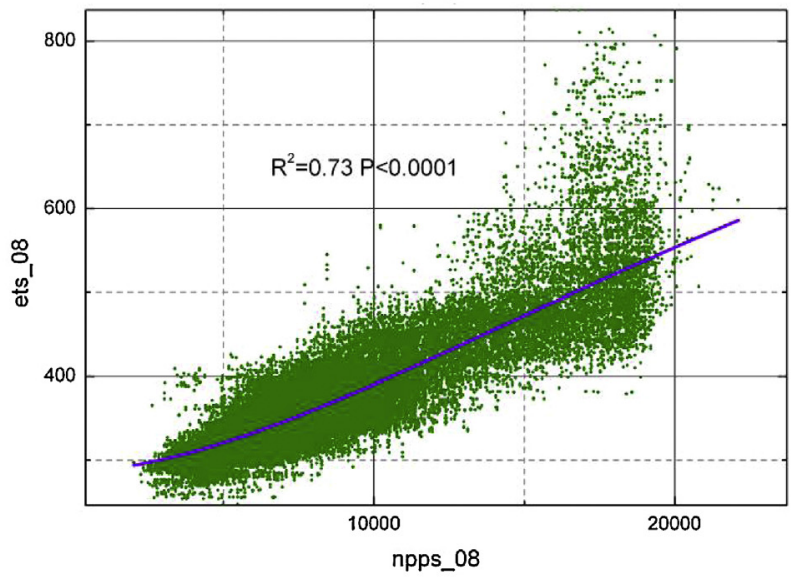

(B)

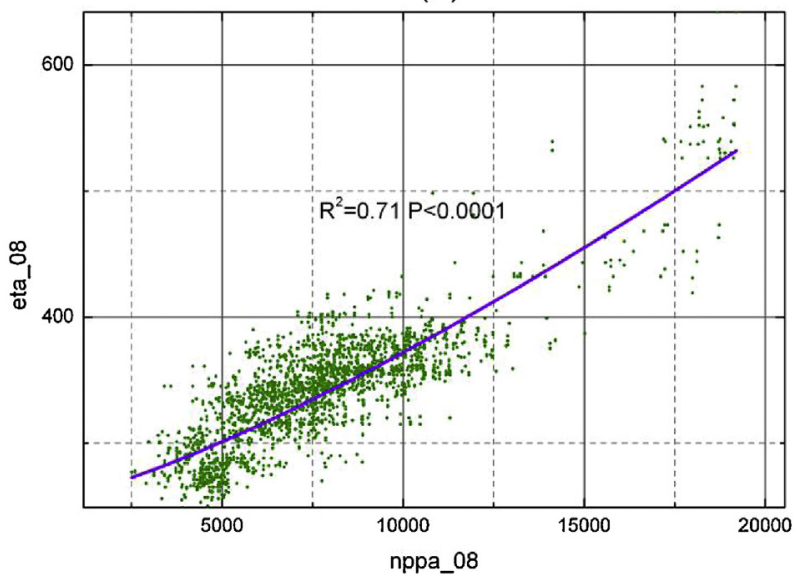

Fig. 4. Synergies between net primary production and evapo-transpiration at grid-cell level.

shrubs after eight years. The growth of grass and its capacity to preserve soil exhibit a closer relationship than the other two types, but it does not mean a bigger increment of SC would appear on the grasslands (Table 2). Our results showed that typical grasslands saved nearly $1.25 \times 10^{5}$ tons soil from removal by wind and runoff.

As a main part of terrestrial productivity, NPP is defined as the difference between carbon fixed by the vegetation during photosynthesis and the carbon released during plant respiration, providing a comprehensive evaluation of ecosystem services and climate change (Crabtree et al., 2009). Equated to the annual carbon increment in wood and foliage litter (DeLucia et al., 2005), NPP increased as more carbon dioxide was transformed into carbohydrate to form the plant material. NPP formed by plant photosynthesis processes reached 4267 tons among which trees generated 400 tons in an area accounts for only $2 \%$ of the whole GFGP area in 2008. Cultivation of forest vegetation has more pronounced effects on the local climate than sparse vegetation (Fig. 4) because forested areas generally have a lower albedo, higher vegetative cover and leaf area index, and higher maximum transpiration rates than most shrub and grass ecosystems (Bonan, 2002; West et al., 2011). The total atmospheric carbon involved in the photosynthesis by shrubs to generate the same formula unit of oxygen was the most, as living organisms depend on chlorophyll content for the conversion of light energy into chemical free energy 
(A)

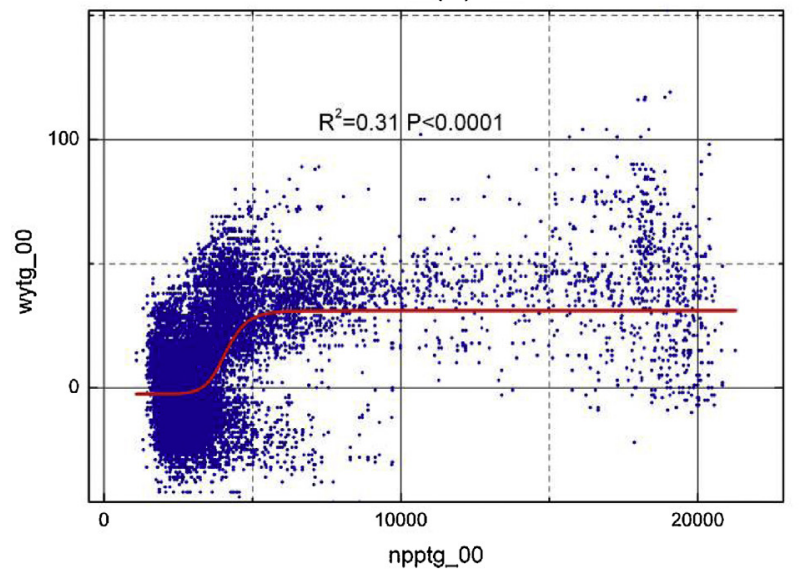

(A)

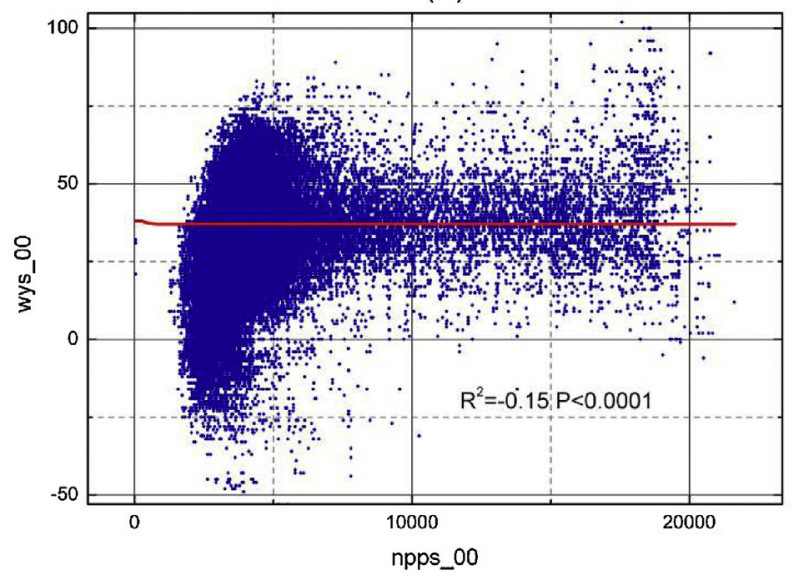

(A)

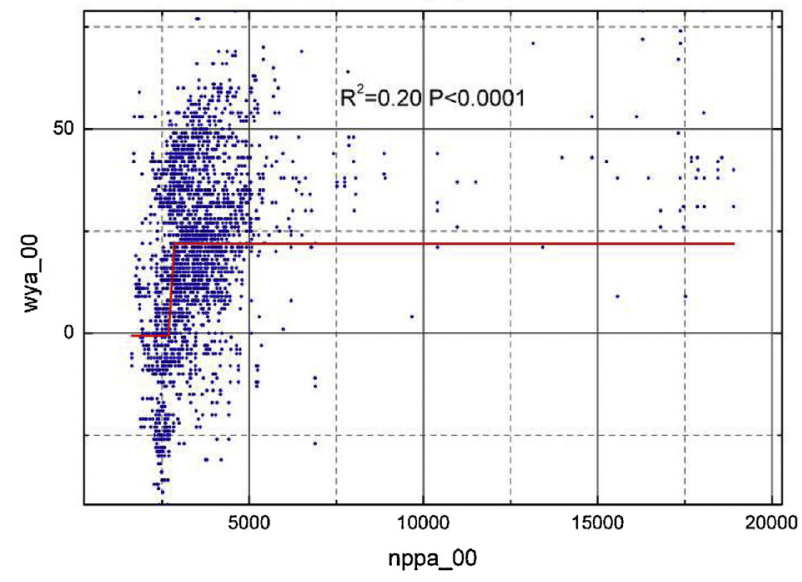

(B)

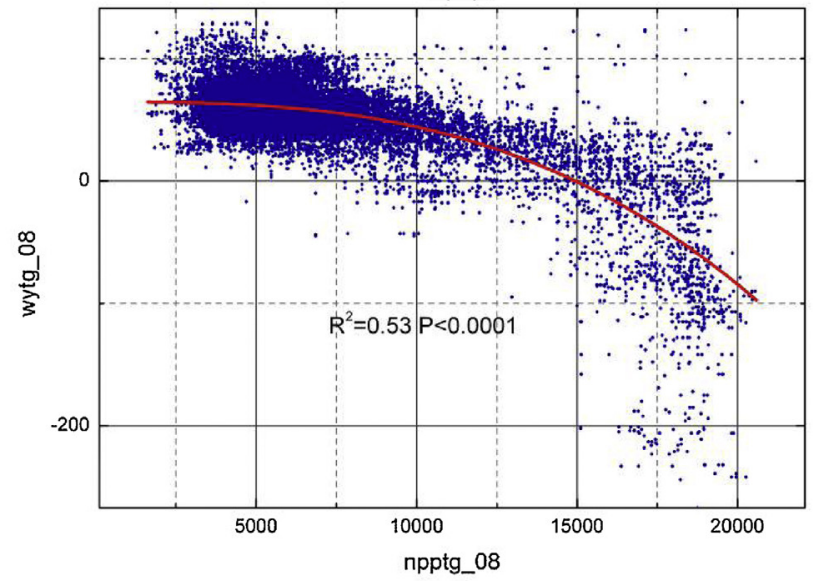

(B)

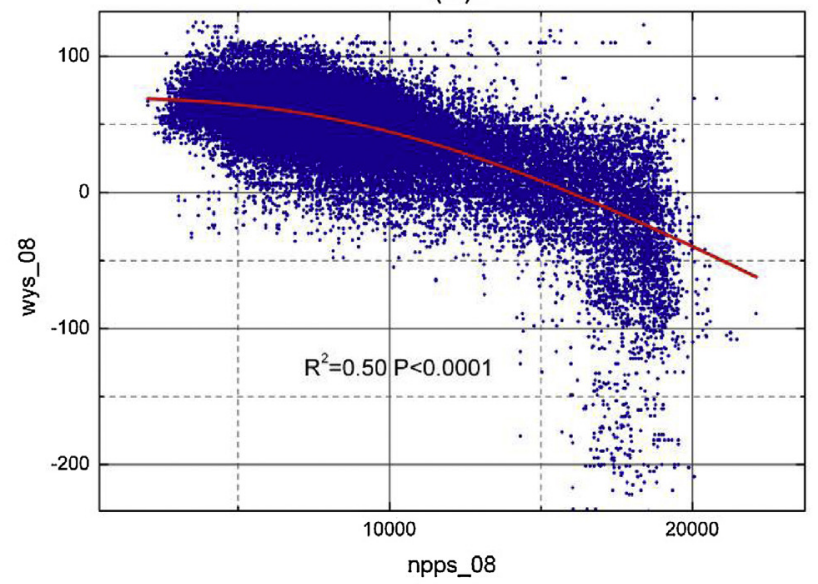

(B)

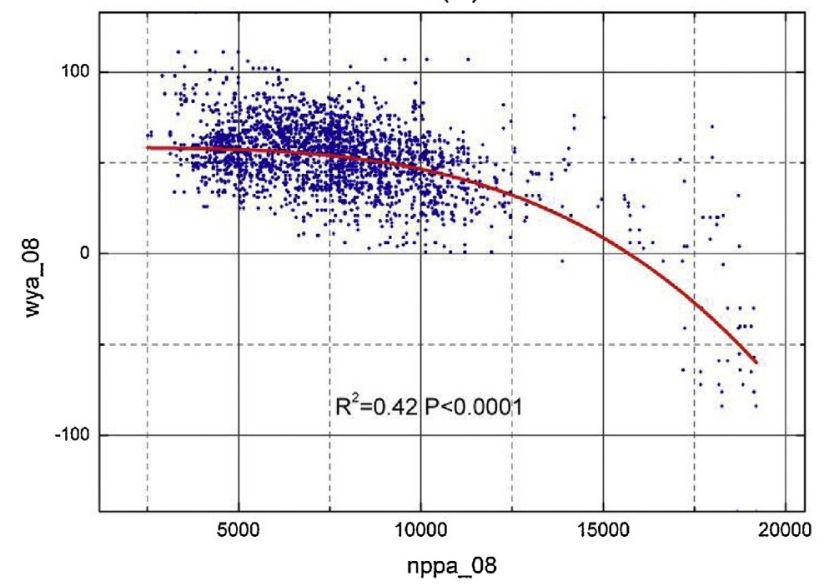

Fig. 5. Tradeoffs between net primary production and water yield at grid-cell level.

(Gest, 1993). Change of the gaseous composition of the atmosphere by a small amount may alter terrestrial and aquatic ecosystem (Costanza et al., 1997). The photosynthesis, transpiration, and evaporation together utilized 572 billion liters of the runoff more than eight years before, driving water from surface stream and precipitation into atmosphere, playing a crucial role in reducing water and soil erosion in the Loess Plateau where vegetation cover restoration is ongoing (Chen and Cai, 2006; Zheng, 2006; Li et al., 2009), while vapor released from the plant foliage may benefit the residents by climate regulation in terms of improving temperature and moisture (Bonan, 2002; Foley et al., 2003; Meir et al., 2006; Chapin et al., 2008).

\subsection{Tradeoffs and synergies for ecosystem-based management}

Ecosystem-based management (EBM) is now regarded as the foremost efforts to conserve biodiversity and restore ecosystems (Samhouri et al., 2010). Implementing EBM requires quantitative methods that can be used to assess overall ecosystem status, evaluate tradeoffs among ESs, and guide management actions (Leslie 
and McLeod, 2007). The GFGP altered the interactions between ecosystems services and made them practical for evaluating and managing the environment of the Loess Plateau. Interactions of pair-wise ESs were revealed to be remarkable for all types of land transformations (Table 3), among which correlations between soil conservation and the regulation of atmospheric carbon remains positive after eight years (Fig. 3), and turned from gradually flatted curves into concurrent rising lines between ET and climate regulation as the plants grows (Fig. 4). WY showed no apparent tendency with NPP in 2000 and was found to decline with the increase of biomass (Fig. 5). In addition, gas regulation service was positively correlated with ET presenting a synergy and negatively correlated with runoff presenting a tradeoff, while SC is developing in spatial concordance with climate regulation service, suggesting that the process of vegetation growth enhances carbon sequestration yet decreased water availability (Fahey and Jackson, 1997; Engel et al., 2005). The increment of biomass storage was the direct result of hydrological change and will affect the WY supply. With the gradual achievement of reduced water loss and soil erosion, tradeoffs and synergies between water, soil, and climate induced by the GFGP provided strong evidence for EBM according to a rational understanding of ecosystem dynamics, and in particular of ecological thresholds (Samhouri et al., 2010).

The evaluation of multiple ecological outputs demonstrates different extent of the synergies or tradeoffs under different types of LU/LC, with the most significant synergy arising in forests (Figs. 3 and 4) and the strongest tradeoff occurring in the region converted to shrubs (Fig. 5). Surface WY and biomass aggregation related negatively (Fig. 5) when cropland were replaced by woody vegetation on a large scale (Liu et al., 2004; Raffaelli, 2004) on account of the large amounts of soil moisture consumed by fast-growing trees (Cao et al., 2009). Noteworthy, a water evapotranspiration rise brought about a concurrent increase of vegetation biomass production with the extensive plantation of trees that generally had lower water-use efficiency. Therefore, afforestation is a more appropriate choice in areas where precipitation is suitable. In the vulnerable arid and semi-arid areas of the Loess Plateau, it would take considerable research to identify the areas where mean annual precipitation is near or below the potential evapo-transpiration (Cao et al., 2009). Our results suggest policy instruments for maintaining ecosystem services through the GFGP that China should target at both natural restoration and artificial restoration. Embedding Platycladus orientalis on gentle slopes and leaving apple trees abandoned turned out to be most simple and convenient way to put the GFGP into practice in northern Shaanxi. Leaving farmland uncultivated had already had large and positive effects on vegetation cover and landscape restoration.

The promotion and restriction between ESs was identified as a cause for concern for the integrity of environment in the study. Green house gases were utilized by plant organisms and their root system growth, consequently influencing water provision and preventing the loss of water and soil by functioning as an erosion control service. The GFGP changed the original equilibrium between provision and regulation services in arid and semi-arid area, believed to be the potential positive externality to the environment effects on regional scale in the first phase of the project. Furthermore, the closeness of the relationship between ESs was demonstrated as distinct for different types of vegetation in the present study, giving profound implications that slow-growing, drought-tolerant vegetation species ought to be the optimal choice for natural restoration on deep slope where soil layer is shallow. Hillside closing and artificial restoration of woody plantation on gentle slopes with deep soil layer is preferable for preserving soil, water, and climate regulation services (Peng et al., 2005; Zhou and Zhao, 2005). Recognition of tradeoffs and synergies enable the expectation of human desired ecosystem services supported by sustainable ecological conservation in relation to potential vegetation restoration strategies. We provided an applicable approach for multiple EBM objectives, although water and carbon cycling is a highly complex and abstract element of ecosystem function, even when it is simplified (Vihervaara et al., 2012). Studies focusing on the causes and courses of the correlations, the nature of matter and energy flow change, and the processes of ESs exchanges in different landscapes at different scales may further raise our awareness of the relationships between ESs.

\section{Conclusions}

Overgrazed pastures and excessive reclamation of sloping lands for the interest of a rapidly growing population have caused severe geomorphologic change and ecosystem degradation. The GFGP has provided huge ecological benefits for regulating climate, water cycling, and soil conservation, with more natural assets worth waiting for, such as fuel wood production. By constructing a quantitative and coherent framework, we reveal the substantial effects and the spatio-temporal dynamics of ESs for EBM decision-making in the context of the human intervention. The explicit upward and downward convex curves of pair-wise interactions between ESs reflected the regulation-regulation synergies and regulation-provision tradeoffs, demonstrating that afforestation on Loess Plateau intensified the interaction between regulation and provision services. Arbores exert a relatively strong influence on preserving soil and regulating atmospheric carbon while shrubs have a stronger inhibiting effect on water yield in a short-term evolution, which gives an important insight into the adoption of strategies in which regional-scale vegetation restoration should mainly aim at arbores in the area where there is sufficient water supply and drought-tolerant shrubs and grasses in the arid area which is widely spread to confirm the policy's validity. However, it would be impossible to develop a scientific basis for incorporating ESs into natural resources for sustainable use without unveiling the mask of the mechanism and deepening the theoretical understanding behind the adaptation between ESs.

\section{Acknowledgements}

The research was funded by the National Natural Science Foundation of China (No. 41230745) and Chinese Academy of Sciences (No. GJHZ1215). We greatly appreciate Prof. Yuan Zeng for strong technical support in data processing. We also thank Dr. Yang Lei and Dr. Yao Xueling for constructive suggestions. Special thanks also extend to the editors and all of the anonymous reviewers.

\section{References}

Allen, R.G., Pereira, L.S., Raes, D., Smith, M., 1998. Crop Evapotranspiration: Guidelines for Computing Crop Water Requirements. FAO Irrigation and Drainage Paper 56. FAO, Rome.

Anderson, M.G., Richards, K.S., 1987. Slope Stability: Geo-technical Engineering and Geomorphology. John Wiley and Sons, New York.

Balvanera, P., Daily, G.C., Ehrlich, P.R., Ricketts, T.H., Bailey, S.A., Kark, C., Pereira, H., 2001. Conserving biodiversity and ecosystem services. Science 291, 20-47.

Bennett, E.M., Balvanera, P., 2007. The future of production systems in a globalized world. Frontiers in Ecology and the Environment 5, 191-198.

Bennett, E.M., Peterson, G.D., Gordon, L.J., 2009. Understanding relationships among multiple ecosystem services. Ecology Letters 12, 1394-1404.

Beskow, S., Mello, C.R., Norton, L.D., Curi, N., Viola, M.R., Avanzi, J.C., 2009. Soil erosion prediction in the Grande River Basin, Brazil using distributed modeling. Catena 79, 49-59.

Boccalandro, H.E., Giordano, C.V., Ploschuk, E.L., Piccoli, P.N., Bottini, R., Casal, J.J., 2012. Phototropins but not cryptochromes mediate the blue light-specific promotion of stomatal conductance, while both enhance photosynthesis and transpiration under full sunlight. Plant Physiology 158, 1475-1484.

Bonan, G.B., 2002. Ecological Climatology. Cambridge University Press, Cambridge, UK.

Bradford, J.B., D’Amato, A.W., 2012. Recognizing trade-offs in multi-objective land management. Frontiers in Ecology and the Environment 10, 210-216. 
Budyko, M.I., 1974. Climate and Life. Academy of Sciences, Main Observatory of Leningrad. Academic Press, New York.

Cai, C.F., Ding, S.W., Shi, Z.H., Huang, L., Zhang, G.Y., 2000. Study of applying USLE and geographical information system IDRISI to predict soil erosion in small watershed. Journal of Soil and Water Conservation 14, 19-24 (in Chinese with English abstract).

Cao, S.X., Chen, L., Yu, X.X., 2009. Impact of China's Grain for Green Project on the landscape of vulnerable arid and semi-arid agricultural regions: a case study in northern Shaanxi Province. Journal of Applied Ecology 46, 536-543.

Carreno, L., Frank, F.C., Viglizzo, E.F., 2012. Tradeoffs between economic and ecosystem services in Argentina during 50 years of land-use change. Agriculture Ecosystems \& Environment 154, 68-77.

Chan, K.M., Shaw, M.R., Cameron, D.R., Underwood, E.C., Daily, G.C., 2006. Conservation planning for ecosystem services. PLoS Biology 4, 2138-2152.

Chapin, F.S., Randerson, J.T., McGuire, A.D., Foley, J.A., Field, C.B., 2008. Changing feedbacks in the climate-biosphere system. Frontiers in Ecology and the Environment 6, 313-320.

Chen, H., Cai, Q.G., 2006. Impact of hillslope vegetation restoration on gully erosion induced sediment yield. Science in China Series D 49, 176-192.

Chen, X.D., Lupi, F., He, G.M., Ouyang, Z.Y., Liu, J.G., 2009. Factors affecting land reconversion plans following a payment for ecosystem service program. Biological Conservation 142, 1740-1747.

Coppin, N.J., Richards, I.G., 1990. Use of Vegetation in Civil Engineering. Butterworths, London.

Costanza, R., d'Arge, R., Groot, R.d., Farber, S., Grasso, M., Hannon, B., Limburg, K., Naeem, S., O’Neill, V., Paruelo, J., Raskin, R.G., Sutton, P., Belt, M.v.d., 1997. The value of the world's ecosystem services and natural capital. Nature 387, 253-260.

Crabtree, R., Potter, C., Mullen, R., Sheldon, J., Huang, S.L., Harmsen, J., Rodman, A., Jean, C., 2009. A modeling and spatio-temporal analysis framework for monitoring environmental change using NPP as an ecosystem indicator. Remote Sensing of Environment 113, 1486-1496.

D’Amato, A.W., Bradford, J.B., Fraver, S., Palik, B.J., 2011. Forest management for mitigation and adaptation to climate change: insights from long-term silviculture experiments. Forest Ecology and Management 262, 803-816.

Daily, G.C. (Ed.), 1997. Nature's Services: Societal Dependence on Natural Ecosystems. Island Press, Washington, DC.

DeLucia, E.H., Moore, D.J., Norby, R.J., 2005. Contrasting responses of forest ecosystems to rising atmospheric $\mathrm{CO}_{2}$ : implications for the global $\mathrm{C}$ cycle. Global Biogeochemical Cycles 19, GB3006, http://dx.doi.org/10.1029/2004GB002346.

Dickie, I.A., Yeates, G.W., St John, M.G., Stevenson, B.A., Scott, J.T., Rillig, M.C., Peltzer, D.A., Orwin, K.H., Kirschbaum, M.U.F., Hunt, J.E., Burrows, L.E., Barbour, M.M., Aislabie, J., 2011. Ecosystem service and biodiversity trade-offs in two woody successions. Journal of Applied Ecology 48, 926-934.

Dymond, J.R., Ausseil, A.G.E., Ekanayake, J.C., Kirschbaum, M.U.F., 2012. Tradeoffs between soil, water, and carbon - a national scale analysis from New Zealand. Journal of Environmental Management 95, 124-131.

Egoh, B., Reyers, B., Rouget, M., Richardson, D.M., Le Maitre, D.C., van Jaarsveld, A.S., 2008. Mapping ecosystem services for planning and management. Agriculture Ecosystems \& Environment 127, 135-140.

Engel, V., Jobbagy, E.G., Stieglitz, M., Williams, M., Jackson, R.B., 2005. Hydrological consequences of eucalyptus afforestation in the argentine pampas. Water Resources Research 41, W10409.

Fahey, B., Jackson, R., 1997. Hydrological impacts of converting native forests and grasslands to pine plantations, South Island, New Zealand. Agricultural and Forest Meteorology 84, 69-82.

Foley, J.A., Costa, M.H., Delire, C., Ramankutty, N., Snyder, P., 2003. Green surprise? How terrestrial ecosystems could affect earth's climate. Frontiers in Ecology and the Environment 1, 38-44.

Foley, J.A., DeFries, R., Asner, G.P., Barford, C., Bonan, G., Carpenter, S.R., Chapin, F.S., Coe, M.T., Daily, G.C., Gibbs, H.K., Helkowski, J.H., Holloway, T., Howard, E.A., Kucharik, C.J., Monfreda, C., Patz, J.A., Prentice, I.C., Ramankutty, N., Snyder, P.K., 2005. Global consequences of land use. Science 309, 570-574.

Fu, B.J., Ma, K.M., Zhou, H.F., Chen, L.D., 1999. The effect of land use structure on the distribution of soil nutrients in the hilly area of the Loess Plateau, China. Chinese Science Bulletin 44, 732-736.

Fu, B.J., Zhao, W.W., Chen, L.D., Zhang, Q.J., Lu, Y.H., Gulinck, H., Poesen, J., 2005. Assessment of soil erosion at large watershed scale using RUSLE and GIS: a case study in the Loess Plateau of China. Land Degradation \& Development 16, 73-85.

Gest, H., 1993. Photosynthetic and quasi-photosynthetic bacteria. FEMS Microbiology Letters 112, 1-6.

Gray, D.H., Sotir, R.D., 1996. Biotechnical and Soil Bioengineering Slope Stabilization. John Wiley and Sons, New York.

Hamon, W.R., 1963. Computation of direct runoff amounts from storm rainfall. International Association of Scientific Hydrology Publication 63, 52-62.

Heal, G.M., 2000. Nature and the Marketplace: Capturing the Value of Ecosystem Services. Island Press, Washington, DC.

Leslie, H.M., McLeod, K.L., 2007. Confronting the challenges of implementing marine ecosystem-based management. Frontiers in Ecology and the Environment 5, 540-548.

Li, D., Bo, F., Tao, J., 2006. Achievements in and strategies for the Grain to Green Program in Hunan Province. Hunan Forestry Science \& Technology 33, 1-5 (in Chinese).
Li, M.A., Yao, W.Y., Ding, W.F., Yang, J.F., Chen, J.N., 2009. Effect of grass coverage on sediment yield in the hillslope-gully side erosion system. Journal of Geographical Sciences 19, 321-330.

Liu, B.Y., Nearing, M.A., Risse, L.M., 1994. Slope gradient effects on soil loss for steep slopes. Transactions of the ASAE 37, 1835-1840.

Liu, F., Huang, C., He, T., Qian, X., Liu, Y., Luo, H., 2002. Roles of Grain to Green Program in reducing loss of phosphorus from yellow soil in hilly areas. Journal of Soil Water Conservation 16, 20-23 (in Chinese).

Liu, G., Wang, Z., Wang, X., 2004. Analysis of dried soil layer of different vegetation types in Wuqi County. Research of Soil and Water Conservation 11, 126-129 (in Chinese).

Liu, J.G., Diamond, J., 2005. China's environment in a globalizing world. Nature 435, 1179-1186

Liu, J.G., Li, S.X., Ouyang, Z.Y., Tam, C., Chen, X.D., 2008. Ecological and socioeconomic effects of China's policies for ecosystem services. Proceedings of the National Academy of Sciences of the United States of America 105 9477-9482.

Long, H.L., Heilig, G.K., Wang, J., Li, X.B., Luo, M., Wu, X.Q., Zhang, M., 2006. Land use and soil erosion in the upper reaches of the Yangtze River: some socio-economic considerations on China's Grain-for-Green Programme. Land Degradation \& Development 17, 589-603.

Loring, P.A., Chapin III, F.S., Gerlach, S.C., 2008. The services-oriented architecture: ecosystem services as a framework for diagnosing change in social ecological systems. Ecosystems 11, 478-489.

Lufafa, A., Tenywa, M.M., Isabirye, M., Majaliwa, M.J.G., Woomer, P.L., 2003. Prediction of soil erosion in a Lake Victoria basin catchment using a GIS-based Universa Soil Loss model. Agricultural Systems 76, 883-894.

Ma, Y., Fan, S., 2005. Ecological-economic effects of Grain to Green Program in desertification areas. Journal of Natural Resources 20,590-596.

Maes, J., Paracchini, M.L., Zulian, G., Dunbar, M.B., Alkemade, R., 2012. Synergies and trade-offs between ecosystem service supply, biodiversity, and habitat conservation status in Europe. Biological Conservation 155, 1-12.

McNally, C.G., Uchida, E., Gold, A.J., 2011. The effect of a protected area on the tradeoffs between short-run and long-run benefits from mangrove ecosystems. Proceedings of the National Academy of Sciences of the United States of America 108, 13945-13950.

Meir, P., Cox, P., Grace, J., 2006. The influence of terrestrial ecosystems on climate. Trends in Ecology \& Evolution 21, 254-260.

Nelson, E., Mendoza, G., Regetz, J., Polasky, S., Tallis, H., Cameron, D.R., Chan, K.M.A., Daily, G.C., Goldstein, J., Kareiva, P.M., Lonsdorf, E., Naidoo, R., Ricketts, T.H. Shaw, M.R., 2009. Modeling multiple ecosystem services, biodiversity conservation, commodity production, and tradeoffs at landscape scales. Frontiers in Ecology and the Environment 7, 4-11.

Operstein, V., Frydman, S., 2000. The influence of vegetation on soil strength. Ground Improvement 4, 81-89.

Peng, Z.H., Dong, L.S., Zhang, X.D., Zhou, J.X., 2005. Anylysis of vegetation restoration strategies in severe soil erosion area of the Loess Plateau in China. Forest Research 18, 471-478.

Piao, S.L., Fang, J.Y., Guo, Q.H., 2001. Application of the CASA model to the estimation of Chinese terrestrial net primary productivity. Acta Phytoecologica Sinica 25 603-608.

Potter, C.S., Randerson, J.T., Field, C.B., Matson, P.A., Vitousek, P.M., Mooney H.A., Klooster, S.A., 1993. Terrestrial ecosystem production: a process model based on global satellite and surface data. Global Biogeochemical Cycles 7 , 811-841.

Potter, N.J., Zhang, L., Milly, P.C.D., McMahon, T.A., Jakeman, A.J., 2005. Effects of rainfall seasonality and soil moisture capacity on mean annual water balance for Australian catchments. Water Resources Research 41, W06007.

Raffaelli, D., 2004. How extinction patterns affect ecosystems. Science 306, $1141-1142$.

Renard, K.G., Foster, G.R., Weesies, G.A., 1997. Predicting Soil Erosion By Water: A Guide to Conservation Planning with the Revised Universal Soil Loss Equation (RUSLE). United States Department of Agriculture, Agriculture Handbook Number 703.

Rodríguez, J.P., Beard Jr., T.D., Bennett, E.M., Cumming, G.S., Cork, S., Agard, J., Dobson, A.P., Peterson, G.D., 2006. Trade-offs across space, time, and ecosystem services. Ecology and Society 11,28.

Samhouri, J.F., Levin, P.S., Ainsworth, C.H., 2010. Identifying thresholds for ecosystem-based management. PLoS One 5, e8907.

Shi, H., Shao, M.G., 2000. Soil and water loss from the Loess Plateau in China. Journa of Arid Environments 45, 9-20.

Sun, G., Alstad, K., Chen, J.Q., Chen, S.P., Ford, C.R., Lin, G.H., Liu, C.F., Lu, N., McNulty, S.G., Miao, H.X., Noormets, A., Vose, J.M., Wilske, B., Zeppel, M., Zhang, Y., Zhang Z.Q., 2011a. A general predictive model for estimating monthly ecosystem evapotranspiration. Ecohydrology 4, 245-255.

Sun, G., Caldwell, P., Noormets, A., McNulty, S.G., Cohen, E., Myers, J.M., Domec, J.C., Treasure, E., Mu, Q.Z., Xiao, J.F., John, R., Chen, J.Q., 2011b. Upscaling key ecosystem functions across the conterminous United States by a water-centric ecosystem model. Journal of Geophysical Research: Biogeosciences 116, G00J05, http://dx.doi.org/10.1029/2010JG001573.

Tallis, H., Goldman, R., Uhl, M., Brosi, B., 2009. Integrating conservation and development in the field: implementing ecosystem service projects. Frontiers in Ecology and the Environment 7, 12-20.

Uchida, E., Xu, J.T., Rozelle, S., 2005. Grain for Green cost-effectiveness and sustainability of China's conservation set-aside program. Land Economics 81, $247-264$. 
Vihervaara, P., Marjokorpi, A., Kumpula, T., Walls, M., Kamppinen, M., 2012. Ecosystem services of fast-growing tree plantations: a case study on integrating social valuations with land-use changes in Uruguay. Forest Policy and Economics 14, 58-68.

Vitousek, P.M., 1997. Human domination of Earth's ecosystems. Science 277, 494-499.

West, P.C., Narisma, G.T., Barford, C.C., Kucharik, C.J., Foley, J.A., 2011. An alternative approach for quantifying climate regulation by ecosystems. Frontiers in Ecology and the Environment 9, 126-133.

White, C., Halpern, B.S., Kappel, C.V., 2012. Ecosystem service tradeoff analysis reveals the value of marine spatial planning for multiple ocean uses. Proceedings of the National Academy of Sciences of the United States of America 109, 4696-4701.
Xu, J.T., Yin, R.S., Li, Z., Liu, C., 2006. China's ecological rehabilitation: unprecedented efforts, dramatic impacts, and requisite policies. Ecological Economics 57, 595-607.

Zhang, K., Li, S., Peng, W., Yu, B., 2004. Erodibility of agricultural soils on the Loess Plateau of China. Soil \& Tillage Research 76, 157-165.

Zhang, W.C., Zhong, S., Hu, S.Y., 2008c. Spatial scale transferring study on Leaf Area Index derived from remotely sensed data in the Heihe River Basin, China. Acta Ecologica Sinica 28, 2495-2503 (in Chinese)

Zheng, F.L., 2006. Effect of vegetation changes on soil erosion on the Loess Plateau. Pedosphere 16, 420-427.

Zhou, X.H., Zhao, J.B., 2005. Climatic change and vegetation restoration on the Loess Plateau. Arid Zone Research 22, 116-119. 